\title{
Cell Viability Studies of Green Synthesised ZnO Nanoparticles for Antibacterial Properties
}

\author{
G. Raghavendra ${ }^{1}$, D. Mahija ${ }^{1}$, T. Sreevani ${ }^{1}$, Anilkumar Yamala $^{2}$, P. Hima Bindu ${ }^{1, *}$ \\ ${ }^{1}$ Department of Physics, Nizam College (OU), Hyderabad, India \\ ${ }^{2}$ School of Engineering Science and Technology, Univeristy of Hyderabad, Hyderabad, India \\ Email address: \\ bindu_phys@yahoo.com (P. H. Bindu) \\ ${ }^{*}$ Corresponding author
}

\section{To cite this article:}

G. Raghavendra, D. Mahija, T. Sreevani, Anilkumar Yamala, P. Hima Bindu. Cell Viability Studies of Green Synthesised ZnO Nanoparticles for Antibacterial Properties. American Journal of Materials Synthesis and Processing. Vol. 2, No. 5, 2017, pp. 56-60. doi: 10.11648/j.ajmsp.20170205.11

Received: August 20, 2017; Accepted: September 6, 2017; Published: September 26, 2017

\begin{abstract}
The synthesis and characterization of zinc oxide nanoparticls (ZnONP's) using Ficus religiosa and Azadirachta indica leaves extracts has been presented in this work. Synthesis conditions were optimized for maximal and narrow size range synthesis of zinc oxide nanoparticles. Fine nanorods were formed. The resultant nanomaterials were characterized using various analytical techniques such as SEM, XRD, FTIR, MTT assay. It is suggested that Ficus religiosa and Azadirachta indica leaf extracts can be effectively used for synthesizing nanoparticles. Also that the green synthesized ZnO nanoparticles can be used as an alternative to existing antimicrobial agents. Nanorods would show good semiconductor properties too.
\end{abstract}

Keywords: Green Synthesis, Nanoparticles, Azadirachta Indica, Ficus Religiosa, Characterization, Antimicrobial, Toxicity

\section{Introduction}

The field of nanomaterials has many applications in science and technology. The synthesis of nanoparticles with specific structure and properties is one of the most important aspects. These studies are extensively done for their magnetic, catalytic activity, electronic, optical, antimicrobial [1], wound healing and anti-inflammatory properties [2]. There are different chemical and physical methods which are more popular for synthesis of nanoparticles. The chemical synthesis methods of $\mathrm{ZnO}$ NP's are chemical precipitation, hydrothermal method, pyrolysis, chemical vapour deposition, etc. In the chemical methods, use of toxic compounds and also their residues limits their applications in the field of medicine. Sometimes the synthesis requires high temperature and pressure or even inert atmosphere [3, 4]. On the other hand, 'Green Synthesis Method' for preparation of nanoparticles is efficient and eco-friendly [5-8].

$\mathrm{ZnO}$ belongs to metal oxide family with photo-oxidising and photo-catalytic ability against chemical and biological species [9]. ZnO NP's have a wide range of applications such as semi-conductor, piezo electric devices, solar cell, pigment, catalysis, electronic devices, cosmetic materials, and also remarkable applications in the field of medicine and agriculture. $\mathrm{ZnO}$ nanoparticles are known to be one of the adaptable inorganic nanoparticles with efficient anti-bacterial activity [10].

Ficus religiosa belonging to Moraceae family, commonly known as Peepal (Ravi) tree is a medicinally important tree species. It is considered a sacred tree in India and is respected by followers of many religions. It is extremely popular in indigenous system of medicine like Ayurveda, Siddha, Unani and Homeopathy. Studies have been carried out in the past that validate the antimicrobial property of Ficus religiosa and have been documented and this tree is still regarded as "Village dispensary" in India [11]. Phytochemical investigation of this plant barks show the presence tannins, saponins, flavonoids, steroids, terpenoids and cardiac glycosides. Each part of the Azadirachta indica plant which is commonly available in India has been used as a household remedy against various human ailments from antiquity and for treatment against viral, bacterial and fungal infections [10]. Several researchers have submitted articles on green 
synthesis of $\mathrm{ZnO}$ [12-18] and other nanoparticles, but each material synthesised has its own significance in terms of experimental conditions and resultant size of the particles. Thus this study focus on the easy synthesis of $\mathrm{ZnO}$ nano particles and study of the morphology, structure and stability of $\mathrm{ZnO}$ using Spectroscopic techniques like: SEM, XRD, FTIR and cytotoxity studies.

\section{Materials and Methods}

\subsection{Preparation of Leaf Extract}

Fresh leaves of Ficus religiosa and AzadirachtaiIndica were collected and washed 4 times with distilled water to remove the dust particles. Wetness was removed from them by placing them on blotting paper. The leaves were microwave dried separately for 4 minutes for Ficus religiosa and 3 minutes for Azadirachta indica. Care was taken to see that they remained green in colour. Then $10 \mathrm{~g}$ of smashed leaves, were added to $100 \mathrm{ml}$ of distilled water and heated at $60^{\circ} \mathrm{C}$ for 30 minutes until the colour of aqueous solution changes from transparent to greenish colour. Then the extract was cooled to room temperature and filtered using filter paper and used for further process.

\subsection{Preparation of ZnONP's}

i) $50 \mathrm{ml}$ Ficus religiosa leaf extract was taken in a glass beaker and $5 \mathrm{gm} \mathrm{ZnNO}_{3}$ was added to it and the solution was heated on a hot plate between $70^{\circ} \mathrm{C}-80^{\circ} \mathrm{C}$ for $55 \mathrm{~min}$. When the solution reduced to deep reddish paste, it was transferred into a crucible and kept in hot air oven at $150^{\circ} \mathrm{C}$ for $45 \mathrm{~min}$ Whitish-yellow soft powder was obtained without any further chemical treatment.

ii) $100 \mathrm{ml}$ of Azadirachta indica leaf extract was taken in a beaker and $5 \mathrm{~g}$ of zinc nitrate was added and heated under continuous manual stirring for 60 minutes, the temperature was maintained $60-70^{\circ} \mathrm{C}$. It reduces brownish-yellow paste. Then the paste is dried in the hot air oven at a temperature of 100 degrees for $60 \mathrm{~min}$. The paste turned into fine whitish yellow powder and is further used for characterisation purposes.

\subsection{Cell Lines and Culture}

Standard murine macrophage cell line (RAW264.7A) procured from ATCC and human epithelial adenocarcinoma (HeLa) cell lines were used and cultured in RPMI-1640 medium containing $2 \mathrm{mM}$ L-glutamine supplemented with $10 \%$ FCS, $100 \mathrm{iU} / \mathrm{mL}$ penicillin and $100 \mu \mathrm{g} \mathrm{mL}$ streptomycin. Cells were cultured at $37^{\circ} \mathrm{C}$ in a humidified incubator at $5 \% \mathrm{CO}_{2}$.

\subsection{MTT Assay}

Mitochondrial/metabolic activities of RAW macrophages and HeLa cells in response to ZnONP's was investigated by Tetrazolium salt, 3-(4,5-dimethylthiazol-2yl)-3,5-diphenyltetrazolium (MTT) assay. Cells were seeded overnight for adhesion. The next day, cells were washed and cultured with different concentrations of polymer for $24 \mathrm{~h}$. Following incubation of cells were washed and incubated with MTT reagent for $2 \mathrm{~h}$ and formazan crystals were dissolved in dimethyl sulfoxide (DMSO) and the absorbance was read at $570 \mathrm{~nm}$ with reference at $630 \mathrm{~nm}$ using multimode plate reader (TECAN; Infinite M200PRO). The percentage of cell viability was calculated.

\section{Results and Discussions}

\subsection{Scanning Electron Microscopy (SEM)}

The Scanning Electron Microscopy (SEM) provides further insight into the morphology and size details of the $\mathrm{ZnO}$ (delete)nanoparticles. The SEM images of ZnONP's are shown in the figures 1 and 2. It revealed the information about formation of crystals in the form of nano-rods and also in nanoscale.

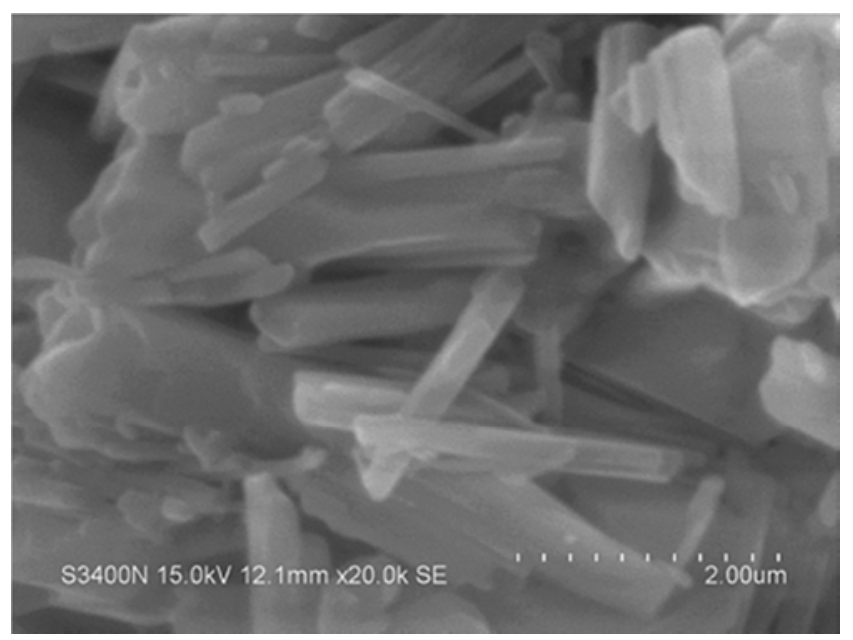

Figure 1. SEM image of Zno prepared using Ficus religiosa.

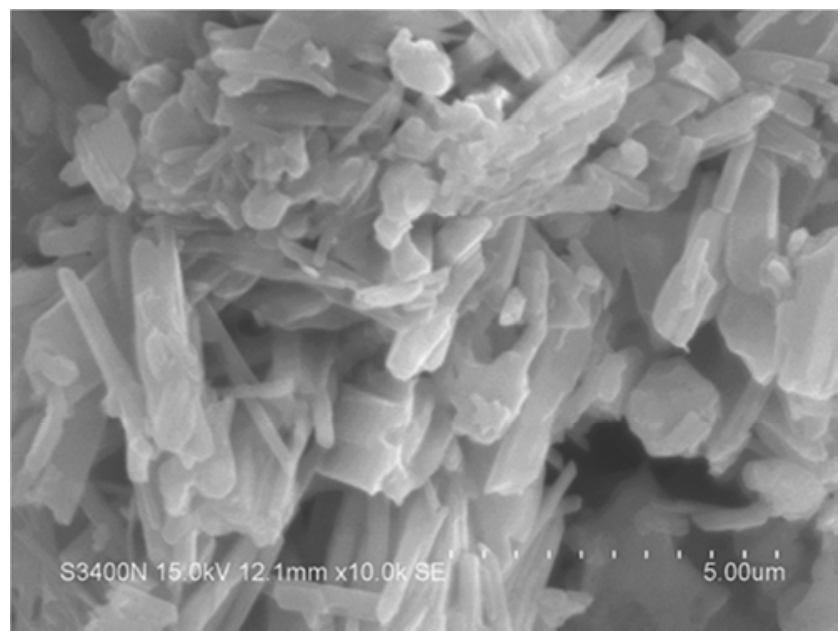

Figure 2. SEM image of Zno prepared using Azadirachta indica.

\subsection{X-Ray Diffractometry (XRD)}

The XRD pattern of $\mathrm{ZnO}$ nanoparticles is shown in figures 
3 and 4 . The observed diffraction peaks at $31.45^{\circ}, 33.95^{\circ}$, $37.50^{\circ}, 47.10^{\circ}, 56.08^{\circ}, 62.51^{\circ}, 67.58^{\circ}$ which correspond to pure $\mathrm{ZnO}$. The peaks of graph are in good match with the literature report [7]. The formations of $\mathrm{ZnO}$ particles was confirmed. The average size of particle was calculated by using Scherrer's formula. Using Ficus religiosa, the average particle size was $23 \mathrm{~nm}$ and that of Azadirachta indica was $25 \mathrm{~nm}$.

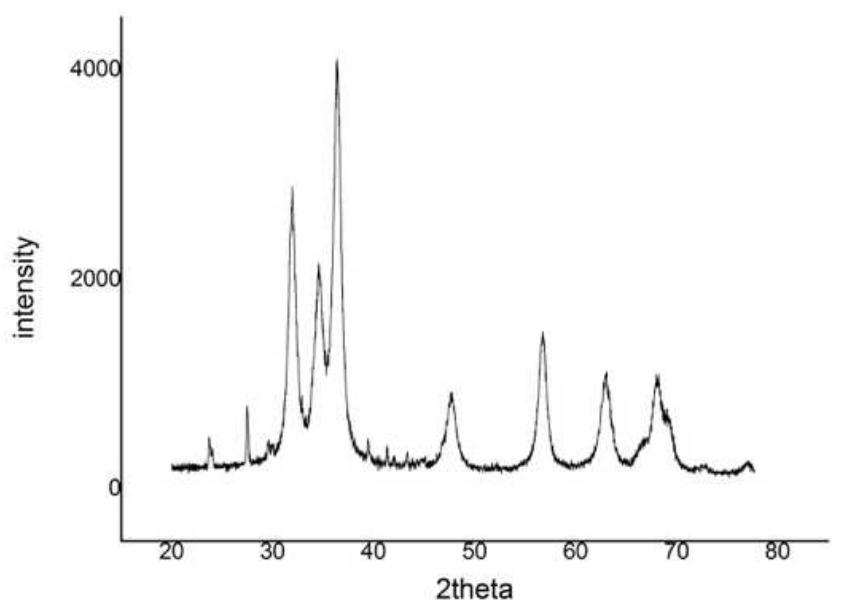

Figure 3. XRD of ZnO synthesised using Ficus religiosa.

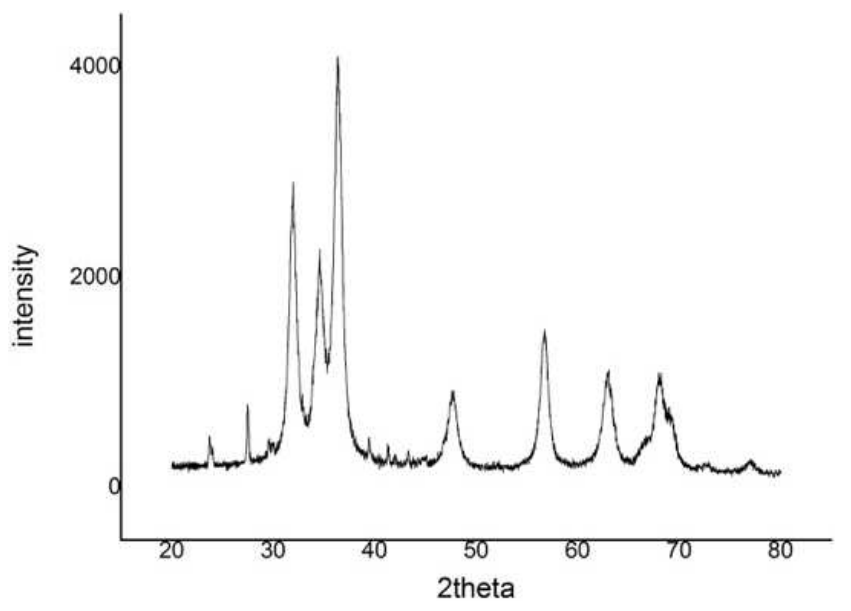

Figure 4. XRD of ZnO synthesised using Azadirachta indica.

\subsection{Fourier Transform Infra-Red (FTIR) Spectroscopy}

The sample peak observed between the band position range $1000-1300 \mathrm{~cm}^{-1}$ in figures 5 and 6 corresponds to $\mathrm{C}-\mathrm{O}$ stretch and $1300-1400 \mathrm{~cm}^{-1}$ corresponds to $\mathrm{N}=\mathrm{O}$ stretch. The band at $1625 \mathrm{~cm}^{-1}-1750 \mathrm{~cm}^{-1}$ attribute to $\mathrm{C}=\mathrm{O}$ stretch indicating the compound to be ketones. The Broad peak at $31000 \mathrm{~cm}^{-1}-3600 \mathrm{~cm}^{-1}$ corresponds to $\mathrm{O}-\mathrm{H}$ and $\mathrm{C}=\mathrm{O}$ indicating the compound to be alcohols and carboxylic acid. The peaks at $790 \mathrm{~cm}^{-1}-840 \mathrm{~cm}^{-1}$ correspond to $\mathrm{CH}$ bend.

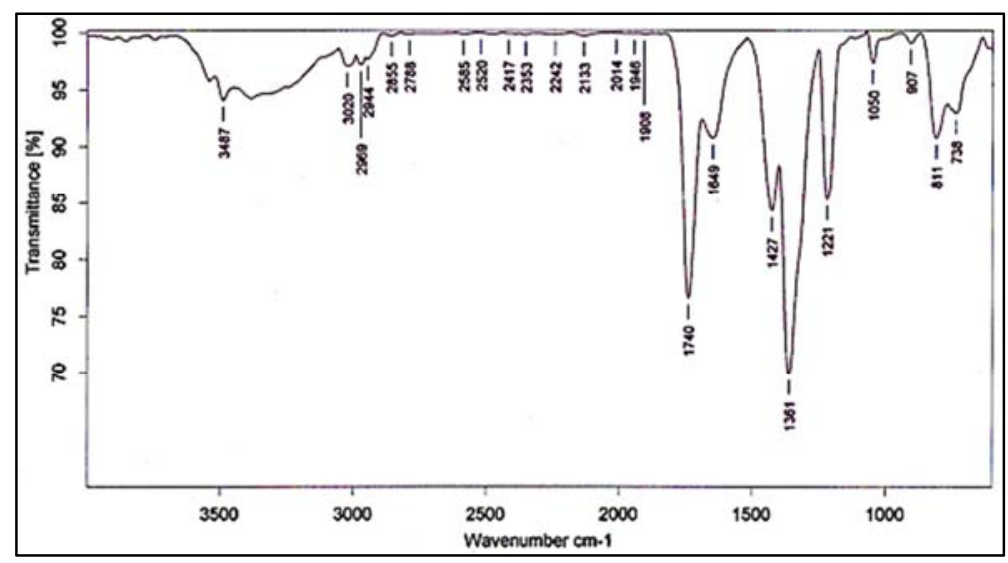

Figure 5. FTIR of ZnO synthesised using Ficus religiosa.

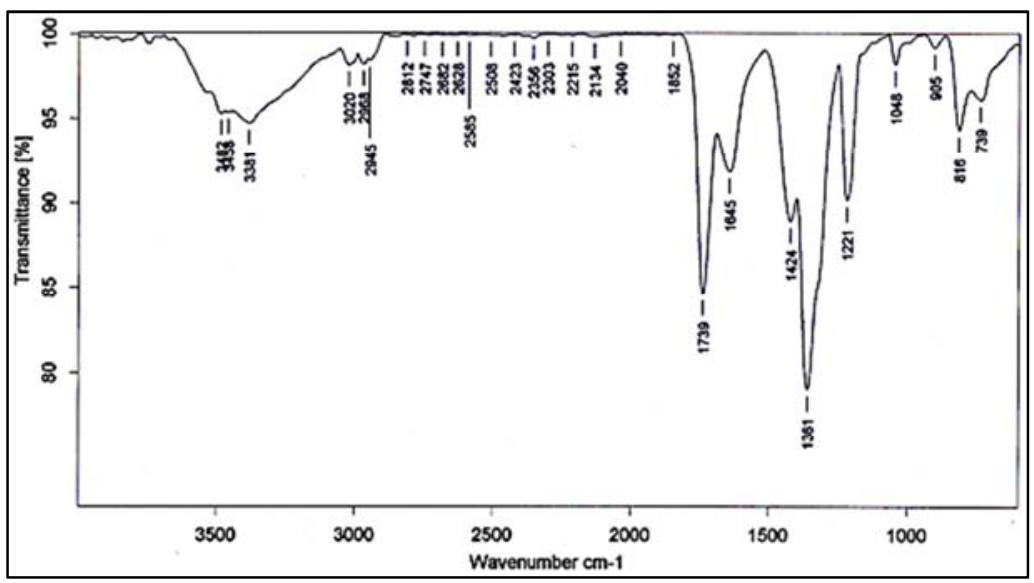

Figure 6. FTIR of ZnO synthesised using Azadirachta indica. 


\subsection{MTT Assay}

After synthesis, we tested the influences of these nanoparticles on cell viability. To that purpose, we checked cytotoxicity associated with $\mathrm{ZnO}$ NP's on both macrophages (Figure 7) and epithelial cells (Figure 8). The $\mathrm{ZnO}$ NP's remained safe in both cell lines tested at the concentration $125 \mu \mathrm{g} / \mathrm{ml}$ tested showing $\sim 75 \%$ cell viability. Interestingly, $\mathrm{ZnO}$ NP's capsules at $62.5 \mu \mathrm{g} / \mathrm{ml}$ showed no sign of toxicity (Figure 7) in both the cell lines tested.

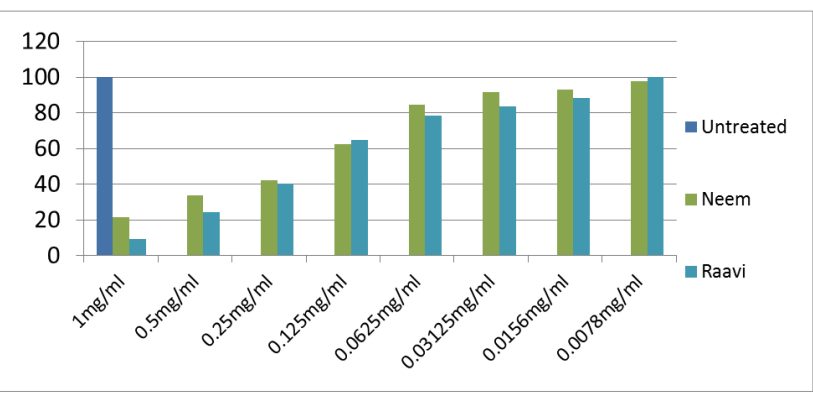

Figure 7. MTT Assay of ZnO@Ravi/Neem synthesised using macrophages.

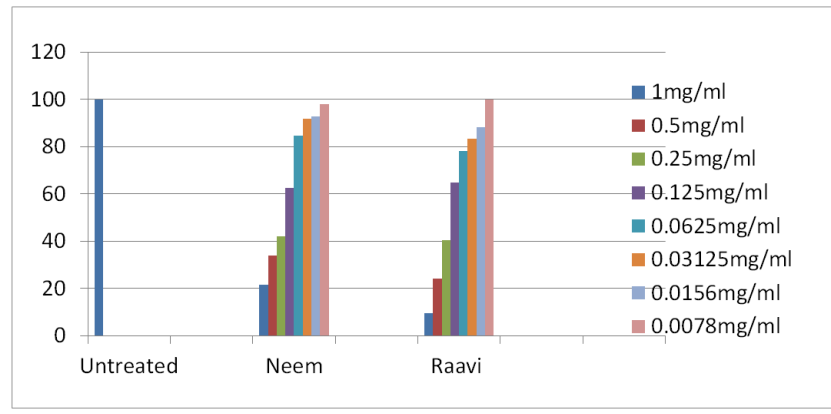

Figure 8. MTT Assay of ZnO@Ravi/Neem using epithelial cells.

\subsection{Anti-Bacterial Studies}

Laboratory grade $\mathrm{ZnO}, \mathrm{ZnO}$ synthesised using Ficus Religiosa extract and Azadirachta Indica were tested for antibacterial properties. Two bacteria, namely: E. Coli and Streptococcus aureus were used for straining on agar plates and the inhibitions were observed. Functionalized $\mathrm{ZnO}$ because of the leaf extracts showed inhibitions of bacterial growth compared to the laboratory grade $\mathrm{ZnO}$ when tested with the two bacteria.

\section{Conclusions}

SEM images confirm the formation of nanosized $\mathrm{ZnO}$ rods, whereas XRD graphs confirm $\mathrm{ZnO}$ crystal structure formation along with the particle size in nano dimensions. Functionalization of nanorods because of Ficus Religiosa and Azadirachta Indica leaf extracts can be clearly visualized in FTIR plots. Zinc Oxide nanorods synthesized using Azadirachta indica and Ficus religiosa leaf extracts did not require any further processing or grinding as in the case of other synthesis methods. The furnace temperatures used were very low $\left(100-150^{\circ} \mathrm{C}\right)$ compared to sol-gel synthesis. Green synthesized Zinc Oxide nanoparticles in the present study show perfect cell viability and good antibacterial activity. It was found that Azadirachta indica and Ficus Religiosa leaves extract are susceptible to the bacterial strains. It is a cheaper and efficient method for obtaining functionalized nanomaterials. The method can be adopted for several other metal and metal oxide synthesis and can be extended to other plant extracts; there is a larger scope of research because of the availability of abundant biodiversity.

\section{Acknowledgements}

Synthesis of nanoparticles was carried out with equipment purchased under DST-FIST scheme of Nizam college. Thanks are due to Prof. M. Ghanshyam Krishna, Dean, SEST for providing us facilities required for characterization of material. The authors are thankful to Ms. Malathi, Technician, Dr. N. Vinod, HCU, for facilitating toxicity and antibacterial studies

\section{References}

[1] V. U. Omoja, A. O. Anaga, I. R. Obidike, T. E. Ihedioha, P. U. Umeakuana, L. I. Mhomga, The effects of combination of methanolic leaf extract of Azadirachta indica and diminazene diaceturate in the treatment of experimental Trypanosoma brucei brucei infection in rats, Asian Pacific Journal of Tropical Medicine, 4, pp. 337-341, 2011.

[2] Kunjal S. Mistry, Zarna Sanghvi, Girish Parmar, and Samir Shah, The Anti-microbial activity of Azadirachta indica, Ocimum sanctum, Mimusops elelngi, Tinospora cardifolia and $2 \%$ chlorhexidine gluconate on common endodontic pathogens: An in vitro study, European Journal of dentistry, 8(2): 172-177, 2014.

[3] M. Hudlikar, S. Joglekar, M. Dhaygude, and K. Kodam, "Latexmediated synthesis of $\mathrm{ZnS}$ nanoparticles: green synthesis approach," Journal of Nanoparticle Research, vol. 14 , no. 5 , article $0865,2012$.

[4] G. Singhal, R. Bhavesh, K. Kasariya, A. R. Sharma, and R. P. Singh, "Biosynthesis of silver nanoparticles using Ocimum sanctum (Tulsi) leaf extract and screening its antimicrobial activity," Journal ofNanoparticle Research, vol. 13, no. 7, pp. 2981-2988, 2011.

[5] Varsha A. Parasharami, Vindya Vati, Bhakti Rabade and Urmil J. Mehta, Recent Antimicrobial and Pharmacological studies in Ficus religiosa, International Journal of current microbiology and applied sciences, Volume 3 Number $1 \mathrm{pp}$. 461-475, 2014.

[6] Inder Kumar Makhija*, Indra Prakash Sharma, Devang Khamar, Phytochemistry and Pharmacological properties of Ficus religiosa: an overview, Annals of Biological Research, 1 (4): 171-180, 2010.

[7] C. Mason, S. Vivekanandhan, M. Misra, and A. K. Mohanty, "Switchgrass (Panicum virgatum) extract mediated green synthesis of silve nanoparticles,"World Journal of Nano Science and Engineering, vol. 2, pp. 47-52, 2012. 
[8] P. Tundo and P. Anastas, Eds., Green Chemistry: Challenging Perspectives, Oxford University Press, Oxford, UK, 2000.

[9] S. M. Reed and J. E. Hutchison, "Green Chemistry in the organic teaching laboratory: an environmentally benign synthesis of adipic acid," Journal of Chemical Education, vol. 77, no. 12, pp. 1627-1628, 2000.

[10] Sidra Sabir, Muhammad Arshad, and Sunbal Khalil Chaudhari Hindawi Publishing Corporation e Scientific World Journal Volume 2014, Article ID 925494, 8 pages http://dx.doi.org/10.1155/2014/925494 Review Article Zinc Oxide Nanoparticles for Revolutionizing Agriculture: Synthesis and Applications, 2014.

[11] D. Gnanasangeetha and D. S. Thambavani, "Biogenic production of zinc oxide nanoparticles using Acalypha indica," Journal of Chemical Biological and Physical Sciences, vol. 4, no. 1, pp 238-246, 2013.

[12] Savita Sharma and Anjali Oudhia, Green Synthesis of $\mathrm{ZnO}$ NPs from various parts of Azhadirachta indica (neem) plant as biotemplates for ani-bacterial applications, AIP Conference Proceedings 1728, 020032; 2016.

[13] A. Geetha, R. Sakthivel, J. Mallika, R. Kannusamy and R. Rajendran, Green Synthesis of Antibacterial Zinc Oxide Nanoparticles Using Biopolymer Azadirachta indica Gum, Orient. J. Chem., Vol. 32(2), 955-963, 2016.
[14] C. Joel and M. Sheik Muhideen Badhusha, Green synthesis of ZnO Nanoparticles using Phyllanthus embilica Stem extract and their Antibacterial activity, Der Pharmacia Lettre 8 (11), 218-223, 2016.

[15] C. M. Noorjahan, S. K. Jasmine Shahina, T. Deepika, Summera Rafiq, Green Synthesis and Characterization of Zinc Oxide Nanoparticles from Neem (Azadirachta indicia), International Journal of Scientific Engineering and Technology Research, Volume. 4, Issue No. 30, 5751-5753, 2015.

[16] D. Saravanakkumar, S. Sivaranjani, M. Umamaheswari, S. Pandiarajan and B. Ravikumar, Green Synthesis of $\mathrm{ZnO}$ Nanoparticles using Trachyspermum ammi Seed Extract for Antibacterial Investigation, Der Pharma Chemica, 8 (7), 173$180,2016$.

[17] Niranjan Bala, S. Saha, M. Chakraborty, M. Maiti, S. Das, R. Basu and P. Nandy, Green synthesis of zinc oxide nanoparticles using Hibiscus subdariffa leaf extract: effect of temperature on synthesis, anti-bacterial activity and anti-diabetic activity, RSC Adv., vol. 5, 4993-5003, 2015.

[18] Tamanna Bhuyan, Kavita Mishra, Manika Khanuja, Ram Prasad and Ajit Varma, Biosynthesis of zinc oxide nanoparticles from Azadirachta indica for antibacterial and photocatalytic applications, Materials Science in Semiconductor Processing 32, 55-61, 2015. 